\title{
Comments
}

\section{ADJUDICATION OF WATER RIGHTS CLAIMED BY THE UNITED STATES-APPLICATION OF COMMON-LAW REMIEDIES AND THE MCCARRAN AMENDMENT OF 1952}

The nature and extent of water rights claimed by the United States is perhaps today a matter of greater concern and interest than ever before. Of equal significance is the doctrine of sovereign immunity as it affects litigation of the Government's claims; for a right without a remedy may be of little value-especially if the right is one against the United States.

This Comment will deal with the problems of sovereign immunity and waiver thereof in the field of water rights. The traditional common-law remedy of bringing suit against the governmental officer concerned in his individual rather than official capacity will be discussed in the hight of recent case law and comment. The scope and extent of the MicCarran Amendment of 1952, ${ }^{1}$ the only general waiver of sovereign immumity by the United States in the area of water rights, will then be explored in some detail.

I

\section{SUITS AGAINST GOVERNMENT OFMICERS}

\section{A. The Sovereign Immunity Problem}

The suit against a governmental officer is the traditional remedy for any person aggrieved by governmental action in a situation where sovereign immunity has not been waived. Foremost among the obstacles to such an action is the objection that the proceeding is in reality one against the United States and hence barred by sovereign immunity. Substantially the same policy considerations are sometimes asserted in terms of the doctrine of indispensable parties; the United States is said to be an indispensable party to the action, which must therefore be dismissed because of inability to join the indispensable party by reason of the bar of sovereign immunity. ${ }^{2}$

1 This statute, reproduced in text and footnote textual material at note 36 infra and hereinafter cited as the "McCarran Amendment," was enacted in 1952 as a rider to the appropriations act for the Justice Department. Department of Justice Appropriations Act, 1953, $\$ \$ 208(a)-(c), 66$ Stat. 560 (1952), 43 U.S.C. $\$ 666$ (1958).

2 This difference in terminology has tendea to compound the difficulties encountered in attempting to construct some rational basis for the cases. The commentators have usually rejected the indispensability doctrine as inapplicable to the problem. See, e.g., Block, Stitls Against Government Officers and the Sovereign Immunily Doctrine, 59 HaRv. L. REv. 1060 (1946), in which it is urged that the indispensability doctrine is not relevant to the sovereign immunity concept, since in reality all suits against government officers are directed against the Government. Block would replace the "fiction" that a suit against wrongful action by a government officer is not a suit against the Government, with the theory that such suits should be barred only when the relief demanded would entail undue interference with the operation of the Government. The problem with his theory is that the ascertainment of "undue interference" is about as difficult as the ascertainment of when the "United States is an indispensable party" or of whether the suit is "substantially against the United States."

A contrary view is put forth in Hart \& WecusLer, THE Frderal Courts AND tae Federai SystEM 1177 (1953), suggesting that only actions in which the United States is a named party- 
In the field of water-rights litigation the last pronouncement on the subject by the United States Supreme Court came in the case of Ickes v. Fox, ${ }^{3}$ decided in 1937. The case held that the United States was not an indispensable party to a suit to enjoin the Secretary of the Interior from enforcing an order wrongfully raising contractual water-use charges imposed upon water-right holders in a federal reclamation project. The theory of the case was that, for purposes of ruling on a motion to dismiss, the allegations of the complaint must be taken as true, and these showed the Secretary's action to be in excess of authority and an interference with property rights vested under state law, acts of Congress, and government contracts entered into by the Secretary's predecessors in office. The Government's characterization of the suit as one for specific performance of a government contract was rejected.

Twelve years after the Fox case the whole field of injunctive suits against government officials was disrupted by the decision in Larson v. Domestic \& Foreign Commerce Corp. ${ }^{4}$ The Court there held a suit brought by an alleged purchaser of a shipment of surplus coal to enjoin the War Assets Administrator from delivering the coal to a subsequent vendee to be a suit against the United States, and directed dismissal for want of jurisdiction. The Court said that injunctive relief might be had against government officials only for an act pursuant to an unconstitutional statute or an act in excess of the scope of statutory authority; a merely erroneous act within the scope of authority (using normal agency principles) would not be enjoinable even though tortious. Moreover, even though the suit would otherwise lie, it would fail if the relief sought required the disposition of public property or undue interference with the conduct of governmental affairs.

In the course of reaching its conclusion in the Larson case the Court rationalized a long line of cases going back at least to United States $v$. Lee, ${ }^{5}$ in a manner leaving little doubt that it intended to restrict narrowly the theory used in Ickes $v$. Fox. Fox itself was distinguished on the theory that the Secretary of the Interior had no statutory authority to reverse the determination of his predecessor. No effort was made to explain why this should not be as much within the scope of authority as the sale and delivery of coal, title to which had already passed to an earlier purchaser (which was the allegation in Larson). A comparison of the two cases would seem to indicate a latent ambiguity in the Larson analysis; a clear distinction is not made between action in excess of statutory authority and action in excess of the scope of statutory authority. Merely erroneous action may be construed as coming within the former category but not the latter; yet the Court used the concepts inore or less interchangeably.

The Larson analysis should not be strong authority outside of the sales-contract area. ${ }^{6}$ It is logically inconsistent with other cases which it purports to reconcile

defendant, or in which property admittedly belonging to the United States is affected, sbould be regarded as actions against the United States, leaving the protection of the Government in other cases in which its interests should not be litigated in its absence to the indispensable party doctrine. On the doctrine of indispensable parties, see generally Reed, Compulsory Joinder of Parties in Civil Actions, 55 MrCH. L. REv. 327, 483 (1957); Comment, Parties: Necessary and Indispensable Parties, 29 Carre. L. REv. 731 (1941).

3300 U.S. 82 (1937).

1337 U.S. 682 (1949). Detailed analysis of the Larson case has been performed elsewhere (see note 8 infra) and is outside the scope of this Comment. The treatment here covers the more general problems presented by the case only as they affect the water-law cases.

E 106 U.S. 196 (1882).

6 The majority in Larson was made up of six justices, one of whom concurred only in the judgment and another of whom, though joining in the opinion of the Court, wrote a brief con- 
and does not overrule. ${ }^{7}$ If strictly applied it would substantially narrow the scope of judicial review of administrative action. It has been vigorously disapproved by the commentators. ${ }^{8}$

The lower federal courts have had difficulty with the Larson doctrine, primarily because if taken seriously it would make judicial inquiry into the validity of most administrative action impossible. ${ }^{9}$ The case in which the problem appears to have been analyzed most extensively is West Coast Exploration Co. v. McKay, ${ }^{10}$ an action for a mandatory injunction to compel the Secretary of the Interior to issue a patent for a tract of land in California, heard en banc before the United States Court of Appeals for the District of Columbia Circuit. Although the court decided for the Secretary and ordered dismissal on jurisdictional grounds, it did so only after considering the merits. The fundamental problem in any suit against a governmental officer is analyzed in McKay as consisting in the fact that jurisdiction is dependent on the outcome of the case on the merits. If the action of the official is indeed wrongful the interest of the Government lies on the side of requiring him to act validly, and it is no protection to the Government to protect the official in his wrongful act. On the other hand, if the official has acted validly the principle of sovereign immunity would bar the suit. Thus, for jurisdictional purposes some assumption inust be made at the outset of the case as to the merits, even though a contrary conclusion may be reached upon trial (if the beginning assumption allows the case to proceed to trial). The rule adopted by the court is to accept as true the allegations of the complaint unless they are so frivolous as to be unsubstantial, and to give these allegations their natural jurisdictional consequences. ${ }^{21}$ The approach is similar to that taken in making a ruling on a general demurrer.

The court in McKay avoided the binding effect of the Larson decision by distinguishing the latter on the same basis upon which the latter had distinguished the earlier precedents such as Fox, i.e., Larson was; said to have involved only erroneous action, while the other cases involved action in excess of authority. Since the issuance of a land patent appears as much with the scope of authority of the Secretary of the Interior as the sale of surplus property is within that of a War Assets Administrator, it would seem clear that the District of Columbia

curring opinion indicating he regarded the case as establishing a rule only as to the sale of property by the Government. The narrow holding of the case would therefore seein to be bimited to the latter point.

7 Cf. Land v. Dollar, 330 U.S. 731 (1947).

8 HART \& WeCHSLER, op. cit. supra note 2, at 1169-77; Davis, Sovercign Immunily in Strils Against Officers for Relief Other Than Damages, 40 CorNeIx L.Q. 3, 18-25, 37 (1954); Counment, Immunity of Government Officers: Effects of the Larson Case, 8 STAN. L. REv. 683 (1956); Counment, The Sovereign Immunity Doctrine and Judicial Review of Federal Administrative Action, 2 U.C.L.A.I. REv. 382 (1955) ; Note, Sovereign Immunily and Specific Relief Against Federal Officers, 55 Colosx. L. REv. 73 (1955).

${ }^{9}$ See Comment, The Sovereign Immanity Doctrine and Judicial Review of Federal Administrative Action, 2 U.C.L.A.L. REv. 382, 391 (1955).

10213 F.2d 582 (D.C. Cir. 1954), cert. denied, 347 U.S. 989 (1954).

11 It may be noted that this rule does not invariably result in finding jurisdiction. Where the complaint alleges that an officer invalidly cancelled a government contract and seeks to require him to carry it out, for instance, the allegation requires that for jurisdictional purposes the contract be treated as in force, and the suit therefore seeks relief (specific enforcement) against the United States. See West Coast Exploration Co. v. McKay, 213 F.2d 582 (D.C.Cir. 1954). Presumably the rationale for such a result is not that there is any reason for protecting the officer who is acting invalidly but that the United States is then truly an indispensable party to the action, since any relief, to be effective, must be awarded against it. The fiction that the suit is against the officer individually is then no longer available. 
Circuit intends to restrict narrowly the Larson rule. ${ }^{12}$ Since most suits against government officials are apt to take place in the District of Columbia, due to the problem of the indispensable superior, ${ }^{13}$ the Supreme Court will probably be obliged to rule on the point again if the language of Larson is to be given full effect.

In the water-law field the cases in the lower federal courts have tended to follow Larson rather than Fox. In two separate cases, Ogden River Water Users' $A s s^{\prime} n$ v. Weber Basin Water Conservancy ${ }^{14}$ and New Mexico v. Backer, ${ }^{15}$ the Tenth Circuit has specifically purported to follow Larson. The case of Hudspeth County Conservation \& Reclamation Dist. v. Robbins ${ }^{16}$ in the Fifth Circuit has treated Larson as at least restricting the rule of Fox. In the Ninth Circuit, on the other hand, the district court case of Rank $v$. Krug has applied the Fox rule without reference to Larson. ${ }^{17}$ The fact situations in the cases vary, although all four cases involve Bureau of Reclamation officials.

Ogden was an action for declaratory and injunctive relief against various federal officials who were commencing construction work preparatory to enlarging a dam to which the plaintiff claimed equitable title and a right of management under contract with the United States. The objection based on Larson appears as the principal ground of decision, although it is alternatively stated that the complaint makes out no ground for equitable relief.

Backer, an action to enjoin federal officials in charge of construction of a dam from lowering the level of a reservoir to a point where fish would die, creating a health menace, expressly treats Larson as overruling $F o x$.

The action in Hudspeth was brought by a group of contractors under section 1 of the Warren Act ${ }^{18}$ seeking to enjoin enforcement of terms included in their contracts pursuant to the statute, subordinating their priorities to the use of water to those of persons in an adjoining reclamation project. The plaintiffs claimed a higher priority under local law. The Fox case was said to be inapplicable, since the official action enjoined in $F o x$ was against persons with rights under the Reclamation Act of $1902,{ }^{19}$ not against Warren Act contractors, and was in violation of federal law, rather than pursuant thereto as in Hudspeth. Larson was said to

12 "Since it is elementary that action or inaction of a public officer beyond or in want of statutory (or constitutional) authority may be corrected by suit against the officer individually and that the Government is not, under such circumstances, a necessary party, the contention that the Larson case rules that even though a public officer is charged with action, or inaction, beyond or without lawful authority this may not be corrected by a suit against tbe officer alone, if the case involves the disposition of public lands, is an extreme contention indeed. Under such a ruling a person who had, under the bomestead laws, fully satisfied the requirements . . . and ... paid the required fees could be denied a patent to the land ... without recourse in the courts. ... Such a denial of recourse to the courts would be abliorrent to the justice according to law contemplated by the Constitution. The due process clause of the Fifth Amendment endows the United States courts with power, even though there is no statutory provision for direct review of the action of a public officer, to protect against arbitrary action by such an officer. No such meaning of the Larson case as is contended for can, in our view, be attributed to the Supreme Court." West Coast Exploration Co. v. McKay, 213 F.2d 582, 596 (D.C. Cir. 1954).

13 See text at note 23 infra.

14238 F.2d 936 (10th Cir. 1956).

15199 F.2d 426 (10th Cir. 1952).

16213 F.2d 425 (5th Cir. 1954), cert. denied, 348 U.S. 833 (1954).

1790 F. Supp. 773, 802 (S.D. Cal. 1950).

1836 Stat. 925 (1911), 43 U.S.C. $\$ 523$ (1958).

1832 Stat. 388 , as amended, 43 U.S.C. $\$ \$ 372,373,381,383,391,392,411,416,419,421$, 431, 432, 434, 439, 461, 491, 498 (1958). 
have narrowly restricted the availability of injunctive relief even if Fox might otherwise be applicable.

Rank v. Krug was brought by persons holding water rights under state law seeking to enjoin various federal officials from interfering with their rights by impounding water at a dam under construction. As in $F o x$, the official action was alleged to be in excess of authority by reason of interference with rights vested under state and federal law, and judgment was for the plaintiffs.

It would seem that the cases in the Fifth and Tenth Circuits have given the Larson rule a very extended scope. The courts may have been influenced by the merits of the cases presented, since all three of the cases contain overtones indicating that an exercise of equitable discretion would have resulted in denial of relief. But decision was not rested on that ground.

The merits of the allegations of the complaints in each of the cases would have been examined if the approach taken in MICKay had been followed. Moreover, even under a broad construction of Larson it would appear that any action for interference with water rights vested under state law should be maintainable where the government officers are subject to the Reclamation Act of 1902, since such conduct would be in violation of section 8 of the act ${ }^{20}$ and would hence be in excess of statutory authority. This, at least, is akin to the basis upon which Larson purported to explain Fox. Only Hudspeth considered this argument, however, and it rejected relief upon the theory that the plaintiffs' rights there were governed by the Warren Act rather than the Reclamation Act. ${ }^{21}$ Whether the result would have been different if only the Reclamation Act had been involved seems uncertain.

Whatever the merits of the cases may have been, nevertheless, the rule adopted is apt to affect meritorious claims as well as nonmeritorious ones. As a policy matter the result in Rank v. Krug, rested squarely on the Fox precedent, is to be preferred; any other rule would make equitable relief against administrative action in the water rights field practically impossible.

\section{B. The Problem of the Indispensable Superior}

Even if the litigant seeking to enjoin the action of a government officer succeeds in passing the hurdle of sovereign immunity, he will still find himself confronted with the doctrine of the indispensable superior officer. The theory here is that where an action against a local officer amounts to an attempt to control the action of his superior, the latter must be joined if the action is to continue. The difficulty presented by the doctrine is that if the indispensable superior is the head of an agency located in Washington he is usually held to have his "official residence" there. Since venue normally exists only at the residence of the defendant in cases founded upon federal-question jurisdiction, ${ }^{22}$ any action involving the

2032 Stat. 390 (1902), 43 U.S.C. $\$ 383$ (1958). The section was specifically beld to limit the authority of the Secretary of the Interior in reclamation projects, in United States v. Gerlach Lire Stock Co., 339 U.S. 725 (1950), where it is said, "By its command that the ... reclamation law should govern the ... projects, Congress directed the Secretary of the Interior to proceed in conformity with state laws, giving full recognition to every right vested under those laws." Id. at 734.

21 Hudspeth County Conservation \& Reclamation Dist. v. Robbins, 213 F.2d 425, 429-32 (5th Cir. 1954).

2228 U.S.C. $\$ 1391$ (1958). The existence of federal jurisdiction on grounds of diversity as well as a federal question does not alter the result. Macon Grocery Co. v. Atlantic Coast Line, 215 U.S. 501 (1910). 
construction of a federal statute must be brought in Washington, D. C., if an agency head located there is an indispensable party.23 Since any water litigation involving a federal official is apt to involve construction of a federal statute, the applicability of the indispensable superior doctrine becomes a matter of significant concern.

The leading case on the subject is Williams $v$. Fanning, ${ }^{24}$ in which the Postmaster General was held not an indispensable party to an action to enjoin a local postmaster from carrying out a fraud order issued by the Postmaster General. The same result was reached two years later in Hynes v. Grimes Packing Co., ${ }^{25}$ an action to enjoin a local Interior Department officer from carrying out a regulation promulgated by the Secretary of the Interior prohibiting fishing in certain Alaskan waters. The cases lay down the principle that the superior officer is indispensable only if the relief sought will require him to take some affirmative action; where the relief sought will expend itself solely on the local official, even though requiring him to ignore his superior's instructions, the latter need not be joined. ${ }^{26}$

Although the rule of Williams $v$. Fanning has eliminated the indispensable superior problem in mail order fraud litigation, the lower federal courts have not been liberal in applying it elsewhere. Water litigation has been no exception. The Tenth Circuit has twice held the Secretary of the Interior an indispensable party to actions against local Bureau of Reclamation officials in which only negative relief was required. ${ }^{27}$ A district court in the Ninth Circuit has, however, followed the Fanning and Hynes cases. ${ }^{28}$ Particularly in the light of the Hynes case, it would seem that the Secretary of the Interior should not be considered an indispensable party in the typical water-litigation case. Even in cases where a physical solution is sought, the indispensability problem should be avoidable by use of a conditional decree enjoining the wrongful activity or requiring compliance with the physical solution in the alternative. Such a decree does not require any action by the superior.

23 Butterworth v. Hill, 114 U.S. 128 (1885). To the same effect is Blackmar v. Guerre, 342 U.S. 512 (1952), which although purporting in one portion of the opinion to reserve the question, later decides it in accord with Butterworth.

24332 U.S. 490 (1947).

25337 U.S. 86 (1949).

26 A good example of a case in which a superior officer has been held an indispensable party, even under the Fonning test, may be found in Stroud v. Benson, 254 F.2d 448 (4th Cir. 1958), cert. denied, 358 U.S. 817 (1958), in which an attempt was made to enjoin the enforcement of an allegedly discriminatory price support regulation as to certain grades of tobacco and to require support at $90 \%$ of parity. The Secretary of Agriculture was held an indispensable party.

The indispensable superior doctrine has been criticized, since it serves only to provide an additional ground for litigation unrelated to the merits of the case. Any government interest would seem adequately protected by the sovercign inmunity doctrine. Since actions against federal officials are customarily defended by the Department of Justice, and U.S. Attorneys are located throughout the United States, there would seem to be no reason why Congress should not provide venue for such actions at the residence of the plaintiff. See Note, Williams v. Fanning Revisited: The Indispensable Superior in Judicial Review of Administrative Actions, 54 Colusx. L. Rev. 1128 (1954); Note, The Doctrine of Indispensable Parties as Applied in Review of Administrative Action, 103 U. PA. L. REv. 238 (1954).

27 Ogden River Water Users' Ass'n v. Weber Basin Water Conservancy, 238 F.2d 936 (10th Cir. 1956); New Mexico v. Backer, 199 F.2d 426 (10th Cir. 1952). Both cases also held the United States an indispensable party. See text at notes 14,15 supra.

28 Rank v. Krug, 90 F. Supp. 773 (S.D. Cal. 1950). McIntire v. United States, 22 F. Supp. 316 (D. Mont. 1937), rev'd on other grounds, 101 F.2d 650 (9th Cir. 1939), which held to the contrary, was decided before the Fanning and Hynes cases. 


\section{C.Is the Judgment Binding Upon the United States?}

A third problem in litigation with government officers concerns the binding effect of a judgment on the merits upon the United States where it is not a party to the action. The normal rule is that the United States is not bound by an action against a government officer and hence may subsequently bring suit on its own behalf and relitigate the question. ${ }^{29}$ There are circumstances, however, where the United States may be bound as a participant in the action even though not a formal party. ${ }^{30}$ Whether this principle may be extended to actions against government officials defended by United States attorneys is not clear, but there would seem to be no good reason why it should not. ${ }^{31}$

\section{Actions in State Courts}

The final problem connected with actions against federal officers concerns actions in state courts. Since such actions depend on the theory that the officer's action is not governmental action if invalid, they may be brought in state as well as federal courts. Under the terms of the Judicial Code any such action now appears removable to federal court, so in practice it may be expected that such litigation will not normally take place in state courts. ${ }^{32} \mathrm{~A}$ related provision appears to require remand to state court whenever it appears the case "was removed improvidently and without jurisdiction, ${ }^{133}$ but presumably this refers to jurisdiction of the subject matter rather than of the parties, so that it would not require remand of cases in which jurisdiction failed because the United States or a superior public officer was held to be an indispensable party. ${ }^{34}$

II

\section{APPLICATION OF THE MCCARRAN AMEENDMENT}

In 1952 Congress for the first time passed a waiver of immunity statute of nation-wide apphication relating specifically and solely to proceedings involving water rights. ${ }^{35}$ This statute, which has come to be known as the McCarran Amendment, may best be discussed by examining it in several rather distinct

29 Hussey v. United States, 222 U.S. 88 (1911); Carr v. United States, 98 U.S. 433 (1878).

30 See United States v. Candelaria, 271 U.S. 432, 444 (1926), in which it was stated that the United States would be bound by a judgment rendered against an Indian tribe seeking to quiet title to certain lands, if the United States employed the counsel for the Indian tribe in the action.

31 See HART \& WeCrSLER, op. cit. supra note 2, at 1178-79, and Davis, supra note 8, at $30-35$, in which the problem is discussed in greater detail.

3228 U.S.C. \&1441(a) (1958). See HART \& WeCrsLER, op. cit. supra note 2, at 1147-48, which discusses the origin of the present provisions.

3328 U.S.C. $\$ 1447$ (c) (1958). See HART \& WeCrSLER, op. cil. supra note 2, at 1029-30, which discusses the origin of the present language in this provision.

${ }^{34}$ New Mexico v. Backer, 199 F.2d 426 (10th Cir. 1952), discussed in text at notes 15, 27 supre, affirmed a jurisdictional dismissal based on the indispensability doctrine without requiring remand to the state court in which the action was begun.

35 Department of Justice Appropriation Act, 1953, \&208(a)-(c), 66 Stat. 560 (1952), 43 U.S.C. $\$ 666$ (1958) (The "McCarran Amendment"-see note 1 supra).

Congress had previously passed statutes waiving sovereign immunity which either did not refer specifically to water disputes or which applied only to particular federal water projects. Thus, the Tucker Act, 28 U.S.C. \& 1346 (1958) and the Tort Claims Act, 28 U.S.C. \$8 267180 (1958), are general waivers of immunity to certain suits which may be applied in the water law area. For a waiver of immunity relating particularly to water law, see $\$ 14$ of the Colorado River Storage Project Act, 70 Stat. 110 (1956), 43 U.S.C. $\$ 620 \mathrm{~m}$ (1958), consenting to the joinder of the United States in suits for enforcement of that act in the Supreme Court. 
aspects. The first two concern the question of the statute's broadness, and involve an inquiry into whether sovereign immunity is meant to be waived only where the determination of water rights as against all users on a stream is sought, or whether the waiver extends to suits directed primarily or even solely against the United States because of its particular use of water. Thirdly, it is important to delve into the possible significance for each case of the source of the particular governmental water rights being adjudicated, with a view to determining whether consent has been given to suits respecting all water rights held by the United States regardless of their source or only to suits concerning rights acquired from certain sources. Next, the question arises as to what special rights the United States may assert by reason of its sovereignty once it has been properly joined under the statute. It should also be determined whether the statute may have any impact when the Government has itself initiated an action. In addition, the statute raises questions with regard to whether the United States may be joined in proceedings before state agencies charged with the administration of the water laws of the various States, or may be joined only in purely judicial proceedings. Finally, several proceduril aspects of the McCarran Amendment will be looked into.

\section{A. Nature of the Proceedings Clearly Intended to be Covered by the McCarran Amendment}

The McCarran Amendment provides, inter alia:

Consent is hereby given to join the United States as a defendant in any suit (1) for the adjudication of rights to the use of water of a river system or other source, or (2) for the administration of such rights, wbere it appears that the United States is the owner of or is in the process of acquiring water rights by appropriation under State law, by purchase, by exchange, or otherwise, and the United States is a necessary party to such suit. 36

It seems clear from the wording of the statute that it applies to the judicial proceedings known as the "general adjudication" or "general determination" action. ${ }^{37}$ Such proceedings, when brought before a court as distinguished from an

3666 Stat. 560 (1952), 43 U.S.C. $\$ 666$ (1958). The renuainder of the statute, omitting those portions relating to service of summons and allocation of costs, is as follows: "The United States when a party to any such suit, shall (1) be deenned to have waived any right to plead that the State laws are inapplicahle or that the United States is not amenable thereto by reason of its sovereignty, and (2) shall be subject to the judgunents, orders, and decrees of the court having jurisdiction, and may obtain review thereof, in the same nanner and to the same extent as a private individual under like circumstances .... . Nothing in this Act shall be construed as authorizing the joinder of the United States in any suit or controversy in the Supreme Court of the United States involving the rights of tbe States to the use of the water of any interstate stream." (Reference bereinafter to "the statute" is to this "McCarran Aunendment.")

37 These proceedings are generally established by statute, although in some States the same purposes may be accomplished by such nonstatutory actions as a suit to quiet title to water rights or for a declaratory judgment. Under the statutory procedure, depending upon the State, the action is brought either by a state adininistrative officer or by a private water user to determine the relative priorities of all the users on a given stream. See, e.g., UTAF CODE ANN. \$§ 73-4-1 to -24 (1953) (action brought by state engineer); Colo. Rev. STAT. ANN. $\$ \S 147-9-1$ to -25 (1953) (action brought by private parties). For purposes of the McCarran Amendment, the proceedings in these States must be distinguished from the administrative proceedings in those States using the "Wyoming system," under which the relative priorities are determined by administrative hearing. See Wyo. Comp. STAт. ANN. \$\$ 41-165 to -192 (1957). This distinction is necessary because of the question of whether the McCarran Amendment applies to administrative hearings, discussed in text at note 102 infra. The California system involves a combination of the administrative and judicial process. It is discussed in text at note 111 infra. 
administrative agency, would clearly be "suits" within the meaning of the statute. ${ }^{33}$ Moreover, although there may be no nominal plaintiff in a "general determination" action, it would seem that the United States may still be a "defendant" as that term is used in the statute. ${ }^{39}$ The decree in such an action "adjudicates rights to the use of water" among the users on the stream. ${ }^{10}$ If the United States is one of the users, it should fall within the broad requirement that it be "the owner of or... in the process of acquiring water rights by appropriation under State law, by purchase, by exchange, or otherwise, ..." at least if the water rights in question are not those peculiar to the sovereign. Since the rights of all claimants on the stream are adjudicated in the action, the United States as a user would normally be a necessary party. 11

The only reported case considering the effect of the statute in a "general determination" suit in which the Government was joined as one of the water users is In re Green River Drainage Area.12 The court found the statute applicable, and determined that although the United States had consented to the suit by virtue of the McCarran Amendment, the statute itself did not confer federal-question jurisdiction on the federal courts. ${ }^{13}$ Thus the case was remanded to the state court,

38 See In re Green River Drainage Area, 147 F. Supp. 127 (D. Utah 1956); cf. Cohens v. Virginia, 19 U.S. (6 Wheat.) 264, 407 (1821); In re Silvies River, 199 Fed. 495, 501 (D. Ore. 1912).

39 The term "defendant" has often been given a bberal and nontechnical meaning. Thus, one whose property is being taken in a condemnation proceeding is a "defendant" even though there is no complaint of wrong on his part. Mason City R.R. v. Boynton, 204 U.S. 570, 579 (1907). There is a similar broad meaning given to "defendant" with respect to the Soldiers' and Sailors' Civil Relief Act. See In re Larson, 81 Cal. App. 2d 258, 183 P.2d 688 (1947); In re Cool's Estate, 19 N.J. Misc. 236, 18 A.2d 714 (Orphans' Ct. 1941). These principles would seem applicable to the word as used in the McCarran Amendment, particularly since those water users who do not initiate the "general determination" action are treated procedurally as defendants. For example, they must be served with notice, and must file their claims, under penalty of having their claims foreclosed by default. See, e.g., Cac. Water CODE $\$ \$ 2577,2578$; Colo. Rev. Stat. Axw. $8147-9-5$ (1953) ; Nev. Rev. Stat. 533.110 (1957). The United States was held to be a "defendant" within the purview of the McCarran Amendment in In re Green River Drainage Area, suprc note 38.

$40 \mathrm{It}$ is to be noted that application of the statute is limited to adjudications not only of the water of a "river system," but also of the water of any "other source." This broad terminology would seem to encompass adjudications of rights to the use of ground water, that being the other major "source" of water. For an example of an adjudication of rights to the use of ground water that would seem to come within this provision of the McCarran Amendment, though without the United States as an interested party, see City of Pasadena v. City of Alhambra, 33 Cal. 2d 908, 207 P.2d 17 (1949), cert. denied, 339 U.S. 937 (1950).

11 The Federal Rules of Civil Procedure define necessary parties as those "who are not indispensable, but who ought to be parties if complete relief is to be accorded between those already parties...." FED. R. Crv. P. 19(b). The cases concerning water adjudications indicate that the United States as a water user on a stream being adjudicated would fall within this generally accepted definition. See Miller v. Jennings, 243 F.2d 157 (5th Cir. 1957), cert. denied, 355 U.S. 827 (1957), rehearing denied, 355 U.S. 885 (1957); California v. United States, 235 F.2d 647, 663 (9th Cir. 1956); In re Green River Drainage Area, 147 F. Supp. 127 (D. Utah 1956); City \& County of Denver v. Northern Colo. Water Conservancy Dist., 130 Colo. 375, 276 P.2d 992, 1011 (1954). Cf. CaL. Water CODE 82765.

42 Supra note 41.

43 It should be noted that the determination of the applicability of the McCarran Amendment in Green River was at best an alternative bolding. The court pointed out that if it were mistaken in holding that the Government had consented to the suit by virtue of the statute, the petition for removal by the Government would still have to be denied as having been made prematurely by one not properly a defendant in the action. The court's indication that the statute does apply to such suits is clear, however, and at the present time stands as the only 
from whence it had come on a petition to remove by the federal government. ${ }^{44}$

It is likely also that the suit to quiet title to water rights would normally come within the statute's ambit. This would be a suit for the adjudication of rights to the use of water, in that the rights of the complainant would be adjudicated as against all rival users on the river system or other source. The condition that the United States be a necessary party to the suit would seem to be met in the quiet-title situation if the United States holds or is in the process of acquiring claims on the same water source, under recent judicial indications that all users on a stream must participate in order to render effective a decree quieting title to water rights on the stream. ${ }^{.5}$ No further obstacles appear in the statute's wording to the inclusion of such quiet-title actions within its scope.

In addition, there is a peripheral area encompassing proceedings which are not strictly quiet title actions but which bear close resemblances to such actions. In this area, no blanket statement may be made as to whether the statute will generally be applicable or not. The facts of each case will be determinative. A recent example of a suit in this peripheral zone is Spanish Fork Irr. Co. v. United States. ${ }^{48}$ Plaintiffs, representing the water users of five canal companies which had made appropriations on the Spanish Fork River, brought a class action against the United States and other users, seeking a declaratory judgment establishing their priority to 390 cubic feet per second of water from the river and also seeking a construction of their contracts with the Government. It was held that the United States had consented to the suit under the McCarran Amendment. Since the purpose of the plaintiffs' action was to settle their water rights in the stream as against all other users, including the Government, the court's holding would seem justified under the statute. The analogy to a quiet-title action was strong.

Consent is given in the McCarran Amendment not only to join the United States in suits "for the adjudication of rights to the use of water," but also in suits "for the administration of such rights...."4 Although it is not clear from the face of the statute what is meant by "suits for the administration of such rights," it is evident from its legislative history that this provision was intended by the sponsor, Senator McCarran, to include actions to settle disputes over the interpretation of a "general determination" or similar decree, and to include other actions affecting the rights determined by such a decree whenever the interrelated rights of all the users on the stream or other water source are involved.

reported judicial determination of the question, although there is some language in Town of Durham v. United States, 167 F. Supp. 436, 439 (DN.H. 1958), in support of the Green River interpretation.

44 Because of the remand order, the court may in fact have been without jurisdiction to decide the question of the applicability of the McCarran Amendment. This is the indication of In re Bear River Drainage Dist., 267 F.2d 849 (10th Cir. 1959). There the United States applied for an interlocutory appeal from an unreported decision of the same federal district court in Utah, in which apparently the identical situation as in Greer River had been presented and decided in accordance with the Green River decision. The application for appeal was denied on the ground that the district court bad left itself without jurisdiction over the cause hy its remand order. Referring to the district court's determination of the McCarran Amendment question, it was said, "A court which held itself to be without jurisdiction attempted to decide contemporaneously a controlling element of the cause." 267 F.2d at 851 . See further discussion at note 138 infro.

15 See California v. United States, 235 F.2d 647, 663 (9th Cir. 1956).

46347 P.2d 184 (Utah 1959).

1766 Stat. 560 (1952), 43 U.S.C. $\$ 666$ (1958). 
It appears from a letter written by the Attorney General of Nevada, ${ }^{48}$ Senator MIcCarran's home State, that at the time the McCarran bill was introduced a dispute existed as to the interpretation of an adjuclication decree governing the respective rights of the water users on the Quinn River in Nevada. An action was brought to settle the controversy, joining all water users mentioned in the decree, including the United States. The Government successfully contended in the federal district court that it had not consented to the suit. Thus, without the Government as a party, the suit had proceeded no further, and the dispute remained unset tled at the time the bill was introduced. The Nevada Attorney General in the same letter included the following passage, referring to this sort of situation:

\begin{abstract}
After such a decree [adjudicating the interrelated rights to the use of water among all users on a stream] was entered and made final by an appeal to our Supreme Court, there remained and remains the administration of those rights and the enforcement of the provisions of the decree by the office of the State engineer and his assistants, and/or the courts of the State necessitating further proceedings in our courts from time to time. It is with respect to the administration of the decreed water rights in the courts that a major difficulty arises where the United States has acquired one or more of the decreed rights for the use of one or more of its departments.49
\end{abstract}

Significantly, the report of the Senate Committee on the Judiciary on this $\mathrm{bill}^{50}$ is based largely upon this letter. Although the foregoing passage of the letter is omitted from the report, it is evident that the omission was due to its specific reference to the Nevada situation, as distinguished from the statements of more widespread application in the remainder of the letter and in the report.51 Since it is so clear that Senator McCarran and his committee had in mind both the Nevada situation described above and the Nevada Attorney General's letter referring to the problems of the situation as "the administration of the decreed water rights," it seems probable that the words "or for the administration of such rights" were inserted in the bill largely to correct such situations.

\title{
B. Proceedings Outside the Scope of the Statute
}

When the suit is neither one for the adjudication of all rights on the stream nor one pertaining to the interrelated rights previously adjudicated, the question of the statute's applicability becomes more difficult. The most complete judicial analysis of the statute in this area is found in the district court decision in Rank v. Krug.52 Plaintiffs, landowners along the San Joaquin River below Friant Dam, sought an injunction and "physical solution" against the United States as a result of prospective action by the Government to impound and divert water at Friant Dam, the Government having allegedly deprived plaintiffs of the reasonable amount of water to which they were entitled under federal and California law. The court pointed out specifically that it was not a suit to establish the separate

18 Incorporated in Hearings on S.18 Before a Subcommittee of the Senate Committee on the Judiciary, 82d Cong., 1st Sess. $46-48$ (1951).

48 In id. at 46.

50 S. REP. No. 755, 82d Cong., 15t Sess. (1951), submitted by Senator McCarran to accompany S. 18.

51 The report is taken almost verbatim from the letter, altering the letter's wording or omitting parts only where the letter refers specifically to Nevada.

52142 F. Supp. 1 (S.D. Cal. 1956). It should be noted at the outset that no appearance in this action was ever made on behalf of the United States, so the court was forced to conslder and decide the many important questions relating to the McCarran Amendment without the assistance of argument by the party most vitally concerned with the construction of the statute. The case is currently pending on appeal before the Ninth Circuit. 
rights of each party along the stream; ${ }^{53}$ thus it was not the "general determination" type of suit. Nor was it in the nature of a quiet-title suit, in which all users, including those above Friant Dam, would have to come in. It was held, however, that the McCarran Amendment was applicable and that the United States had therefore consented to the suit.

The key to the court's holding is its interpretation of the phrase permitting suits for "the adjudication of rights to the use of water of a river system or other source." "54 The court in Rank v. Krug reasoned that since the essence of the action was a claim of right to the use of water of the San Joaquin by the plaintiffs, the suit necessarily involved an "adjudication" of plaintiffs' "rights to the use of water" as a prerequisite to the granting or denying of the injunctive relief and physical solution prayed for, and thus fell within this provision of the statute. However, it is questionable whether suits directed primarily against the Government or against those claiming under it are within the purview of the statute, despite the fact that such suits would necessarily involve the settling of a dispute over water rights between opposing parties to the litigation.

First, it is important to analyze the use in the statute of the phrase "adjudication of rights to the use of water." This phrase, or its variations, is found in both the case and statutory water law of the Western States to have a somewhat restricted and technical meaning. It is understood to describe the process by which water rights may be established as against all other users on a stream or on the water source in question. ${ }^{55}$ This might be done by a proceeding in the nature of a quiet title action ${ }^{56}$ or, more frequently, by the "general determination" type of proceeding, whether statutory ${ }^{57}$ or not, ${ }^{58}$ brought to determine all rights of the individual users inter sese. A suit for the "adjudication of rights to the use of water," under the accepted usage of the phrase, would therefore be one in which the plaintiff in a quiet title suit, or each claimant in a "general determination"

53 Rank v. Krug, 142 F. Supp. 1, 36 (S.D. Cal. 1956).

54 The court also discussed each of the other provisions in the first sentence of the statute, rejecting all suggestions that each or any of these provisions negated the Government's waiver of immunity to such a suit.

55 E.g., California v. United States, 235 F.2d 647, 663 (9th Cir. 1956); CAL. WATER COdE $\$ 2525$ ("determination of the rights of the various claimants to the water of that stream system") ; Cor.o. REv. Stat. Axw. \$147-9-1(2) (1953) ("Adjudication shall mean an adjudication proceeding or suit to fix the priorities of water rights in a given water district."); IDABO CODE Axix. $\$ \$ 42-1401$ to -1405 (1947) ("Adjudication of Water Rights"); NEv. REv. STAT. $\$ \S 533.090-320$ (1957) ("Adjudication of Vested Water Rights"); N.M. STAT ANN. \$ 75-4-6 (1953) ("suit for the determination of a right to use the waters of any stream system"); ORE. REV. STAT. \$ 539.020 (1957) (suit "for the determination of rights to the use of water"); WASF. REv: CODE $\$ \S 90.12 .010-.140$ (1951) ("Determination of Water Rights"); Wyo. CoMp. STAT. Axx. \$\$41-165 to -192 (1957) ("Adjudication"). Cf. Reno v. Richards, 32 Idaho 1, 178 Pac. 81 (1918), which uses tbe exact words used by the McCarran Amendment, to describe the proceedings by which all the interrelated rights on the stream are determined.

56 California v. United States, supra note 55.

57 E.g., City \& County of Denver v. Northern Colo. Water Conservancy Dist., 130 Colo. 375, 276 P.2d 992 (1954); Eden Irr. Co. v. District Court, 61 Utah 103, 211 Pac. 957 (1922). The statutory "general determination" action has sometimes been equated with the quiet-title suit. See Sain v. Montana Power Co., 84 F.2d 126, 127 (9th Cir. 1936); cf. In re Green River Drainage Area, 147 F. Supp. 127, 139, 146-47 (D. Utah 1956).

58See Fleming v. Bennett, 18 Cal. 2d 518, 116 P.2d 442 (1941), in which a suit of this nature was brought without resort to the special Cahifornia "statutory adjudication" procedure, though it was referred to what is now the state water rights board as referee, in accordance with a statutory provision not relating specifically to suits to determine relative priorities of water rights. There is nothing in the McCarran Amendment or in its legislative history which would exclude nonstatutory procecdings from its application. 
action, seeks to adjudicate with finality his rights to the use of water against each other user. The phrase normally would not comprehend an action brought against a particular user or users for alleged damage done to the complainant's water rights. When a federal statute uses words, such as these, which have an accepted technical meaning in the area of the country primarily affected by the statute, it would seem anomalous to construe them as conveying more than this accepted technical meaning. If this is so, the "adjudication" necessary to the granting of relief in Rank v. Krug would not fall within the purview of the McCarran Amendment and therefore could not support a waiver of sovereign immunity under the statute.

It is to be noted in this regard that the "adjudication" portion of the McCarran Amendment gives consent to join the Government only in a "suit ... for the adjudication of rights to the use of water." 59 This would seem to refer to a suit the purpose of which is to "adjudicate" water rights (in the "adjudication" sense indicated above), rather than a suit primarily for injunctive or other such in personam equitable relief. Although the parties did seek a "physical solution" in Rank v. Krug as well as an injunction, ${ }^{60}$ the solution sought was not one settling rights as against all adverse claims on the streain but rather one concerning primarily the settlement of a dispute between two particular groups of water users who did not claim to represent all the stream's users.

Nor would Rank v. Krug seem to be a suit "for the administration" of rights to the use of water, within the meaning of the statute. Although it might be argued that the entire state statutory water law is an "administration" of all water rights in the State and that the provisions in the state laws for adjudication of the interrelated rights of water users are a part of such "administration," it does not follow that all suits to enforce state-recognized water rights fall within the McCarran Amendment provision consenting to suits "for the administration of such rights." If this provision of the statute refers to the "administration" of water rights in the sense that the entire state water law may be an "administration" and suits brought under it may be suits for the "administration of water rights," the provision would include within its meaning "suits for the adjudication of rights to the use of water" and there would be no reason to state disjunctively the "adjudication" and "administration" provisions in the statute, nor in fact would there be any reason to express the "adjudication" provision at all. In view of this, it seems more likely that "the administration of such rights" refers to the administration of adjudicated water rights. Under this interpretation, the "administration" provision is given a straightforward construction which complements the preceding "adjudication" provision. Such an interpretation is supported by the legislative history of the statute, in which the only references to the "administration" provision clearly view the phrase as meaning the process of settling disputes over rights decreed in a "general determination" type of suit.62

$\Delta 966$ Stat. 560 (1952), 43 U.S.C. $\$ 666$ (1958). (Emphasis added.)

60 The fact that an injunction might issue as an incident of the adjudication of rights on 2 stream probably would not prevent the statute from applying in a proper suit. Such a suit, however, would not be the usual injunctive proceeding, but rather would be a suit for the adjudication of wates rights in which the injunction might be a means of enforcing the determination of relative priorities among users.

61 See Comment, 29 Rocky MT. L. REv. 407 (1957), taking the position that the statute was correctly applicd in Rank v. Krug.

62 See text at note 48 supra. See also S. REP. No. 755, 82d Cong., 1st Sess. 4-5 (1951). Nevada law specifically provides for the "administration" of water rights in certain cases, in the sense suggested by the text. NEv. REv. Stat. $\$ 533.310$ (1957). 
Moreover, the legislative history contains affirmative indications that the statute as a whole was intended to apply only to suits for the determination of rights as against all other claimants. This appears most clearly in a letter from Senator McCarran to Senator Warren G. Magnuson in response to the latter's concern that suits might be brought under the statute to block or delay such federal developments as the proposed Hells Canyon project. Senator McCarran wrote:

S. 18 is not intended to be used for the purpose of obstructing the project of which you speak or any similar project and it is not intended to be used for any other purpose than to allow the United States to he joined in a suit wherein it is necessary to adjudicate all of the rights of various owners on a given stream. This is so because unless all of the parties owning or in the process of acquiring water rights on a particular stream can be joined as parties defendant, any subsequent decree would be of little value.63

This statement, backed by the report of Senator McCarran's committee, is a further indication of the rather narrow meaning to be given the provisions in the statute consenting to suits for the "adjudication" or "administration" of rights to the use of water.

Further credence to the argument that the McCarran Amendment probably was not intended to apply to such cases as Rank $v$. Krug is found in the fact that it gives consent only to "join" the Umited States as a necessary party defendant. This would indicate at least that the statute does not apply when the Government is made a sole defendant, since it could not then be "joined" as a defendant. The appearance of the word "joim" in the statute is in fact best explained by the theory, supported by the available legislative history, that the statute is ineant to apply only to suits for the determination of individual water rights in which each water user must be "joined." 64 Although the United States was not the sole defendant in Rank v. Krug, it and its agents were the primary defendants. It was not a case of "joining" the Government as one of many necessary defendants to the action, but rather one of "joining" it in order to obtain more complete relief than might have been available by suing only its agents. ${ }^{65}$

One further aspect of the McCarran Amendment analysis in Rank v. Krug should be considered at this point. The court noted that although Congress has recognized vested water rights in private parties as agamst the United States, there had never been a way of enforcing those rights except by equity suits brought against government officials. Consequently, the court reasoned that the very purpose of the McCarran Amendment was to provide a procedure whereby these

63 This letter appears in S. REP. No. 755, 82d Cong., 1st Sess. 9-10 (1951). Although it appears from the report that several representatives of the Government feared this bill would open the door to piecemeal adjudication of water rights and multiplicity of suits, such beliefs were expressed in the context of governmental arguments against the bill, and cannot be taken as evidence that the bill was intended to permit suit against the United States in situations in which all rights on a stream are not being adjudicated. Nor does the mere passage of the statute without any substantial changes after these beliefs were expressed indicate any ratification of the Government's previous interpretation.

64 This argument as to the significance of the word "join" in the statute is made in Town of Durham v. United States, 167 F. Supp. 436 (D.N.H. 1958).

65 The court in Rark v. Krug did recognize the use of the word "join" in the statute, but did not consider its possible significance to the argument that the statute was meant to apply to suits involving all users on the stream. Instead, the court found it to indicate that the Government could be "joined" in pending suits. Although this gives the word a perfectly natural meaning, and although it may very well be that the statute was meant to permit joinder of the Government in the property type of pending suit, it is doubtful that the word was meant $2 s$ the court viewed it. 
rights could be litigated against the sovereign. Unquestionably there are compelling reasons in favor of permitting such rights to be protected against governmental encroachment; however, there does not seem to be sufficient indication either from the words of the statute or from its legislative history that such a broad waiver was intended. The court's reliance on the legislative history of the statute for its result $t^{\mathrm{Bb}}$ would seem to be refuted by the exchange of letters between Senators MICCarran and MIagnuson, ${ }^{67}$ which were incorporated into the Senate report on the bill and which explicitly state that the statute contemplates no such broad waiver. Thus, despite policy reasons in favor of a congressional waiver of sovereign immunity in suits to enforce private water rights through equitable rehef, Congress does not appear to have provided such a waiver in the McCarran Amendment.

Confronted rith a set of -facts very similar to those in Rank v. Krug, the Court of Appeals for the Fifth Circuit, in Miller v. Jennings, ${ }^{88}$ has recently held the MicCarran Amendment inapplicable. This was an action brought against the United States, its reclamation officials, and several other individuals for a declaratory judgment and injunction to protect plaintiffs' water rights from diversion by the Rio Grande Reclamation project. The court reasoned that to "adjudicate" the rights on a stream, all persons who have rights must be before the tribunal. It rejected the plaintiffs' argument that all persons having any interest in the subject matter of the suit were parties or were members of a class represented by the parties, and thus found no consent to the suit under the statute. Although the result of the case appears to be correct under the statute, the court's analysis seems to leave room for some question. Under the court's reasoning, apparently if the plaintiffs had brought an identical suit and had somehow managed to join all persons with rights on the Rio Grande River, consent by the United States to the suit would be found in the MICCarran Amendment. For the reasons discussed above in connection with Rank v. Krug, however, it is doubtful that the statute was meant to apply in such a situation. So long as the crux of the action remained a dispute over injury caused by the Rio Grande Reclamation project, the fact that all water users on the river were in court would not seem to render the statute applicable. Thus it must be concluded that the participation of all water users in an action, though possibly necessary for a suit to immunize water rights from all

${ }_{66}^{6}$ The court quoted at some length from S. REP. No. 755, 82d Cong., 1st Sess. (1951), first setting out a portion of that report dealing with the establishment of water rights in the West and dealing with Congress' recognition of such rights. The portion of the report, as quoted in 142 F. Supp. at 82, continued: "It is most clear that where water rights have been adjudicalcd by a court and its final decree entered, or where such rights are in the course of adjudication by a court, the court adjudicating or having adjudicated such rights is the court possessing the jurisdiction to enter its orders and decrees with respect thereto and thereafter to enforce the same by appropriate proceedings. *** Unless Congress has removed such immunity by statutory enactment, the bar of immunity from suit still remains and any judgment or decree of the State court is ineffective as to the water right held by the United States. Congress has not removed the bar of immunity even in its own courts in suits whorein water rights acquired under State law are drawn in question. The bill $(S .18)$ was introduced for the very purpose of correcting this situation and the evils growing out of suck immunity....'" [Italics are the court's.]

However, it is apparent from that portion of the report onitted by the court in the middle of the quotation that these statements refer to the problem of sovereign immunity in the "general determination" type of suit and in proceedings for the "administration" of interrelated water rights. Thus the court's reliance on this legislative history scems questionable.

67 See text at note 63 supra.

68243 F.2d 157 (5th Cir), cert. denied, 355 U.S. 827, reheasing denied, 355 U.S. 885 (1957). 
claims of others and therefore possibly a prerequisite to the application of the McCarran Amendment, is not in itself sufficient to bring the statute into operation.

The pertinence of the MICCarran Amendment to injunctive proceedings against the Government has also been tested recently in Town of Durham v. United States, ${ }^{69}$ in which two municipalities sought to enjoin the United States and others from acquiring by eminent domain the underground water sources allegedly owned by the municipalities. It was held that the statute had not given consent to suit in this situation. The court relied on the legislative history of the statute and on the fact that it authorizes a plaintiff only to "join" the United States, arriving at the conclusion that the statute did not waive sovereign immunity for the purpose of allowing a determination of the Government's right to condemn property by eminent domain. Interestingly, the court in Durham distingnished Rank v. Krug on the ground that there the plaintiffs had vested rights without a remedy unless the statute applied, whereas in the condemnation situation an adequate remedy is available under the condemnation statute. ${ }^{70}$ Although such a distinction does exist, the two cases seem to stand opposed on their basic views of the breadth to be given to the McCarran Amendment.

Although the argument is persursive that a broad remedy should be provided against the sovereigu just as againss a private party for damage done to recognized water rights, it does not appear t/3at the McCarran Amendment is intended to grant such a remedy. Were the indications in the statute and in its legislative history a little less uniformly again $/ /$ the broad waiver construction, the policy reasons in favor of bringing the sove:eign to answer for such wrongs as it may commit might dictate that no quarrel be taken with such applications of the statute as found in Rank v. Krug. However, the terms of the statute, supported by its legislative history, seem to lead to the tonclusion that no broad waiver was intended ${ }^{71}$ and that the statute must be limit $d$ in its application to suits to adjudicate the rights of a user or to determine the nterrelated rights of each individual user, where all the users on the stream or ol her water source are necessary parties.

\section{The Importance of the Source of the Government's Water Rights}

The Government may acquire water rights in several ways. It may acquire them by appropriation in accordance with state procedures, as any private individual might. ${ }^{72}$ Similarly, in States recognizing riparian rights, it may obtain rights by virtue of its ripariar landholdings. ${ }^{73}$ The Government may also purchase the

69167 F. Supp. 436 (D.N.H. 1958).

70 Act of Feb. 26, 2931, § 1, 46 Stat. 1421, 40 U.S.C. \& 258a (1958).

71 The Supreme Court has enunciated the rule that statutes relinquishing sovereign immunity must be strictly construed. McMahon v. United States, 342 U.S. 25, 27 (1951); United States v. Sherwood, 312 U.S. 584, 590 (1941). Although it might he argued on the basis of this principle alone that the McCarran Amendment grants no broad waiver of immunity in suits alleging injury to private water rights, such a principle is of real help in construing a statute only when the intention of Congress cannot be gleaned from the statute itself. The McCarran Amendment, both on its face and in its legislative history, mdicates its rather restricted coverage. There would seem to be no need to apply the strict construction principle in this situation, as it is little more than a make-weight to the argument that the fairly narrow scope of the statute is apparent on its face.

72 This will normally be the case when the Government is proceeding under the Reclamation Act of 1902, \& 8, 32 Stat. 390, 43 U.S.C. $\$ 383$ (1958), which requires it to proceed in conformity with state law. See United States v. Gerlach Live Stock Co., 339 U.S. 725 (1948).

${ }^{73}$ Cf. United States v. Fallbrook Pub. Util. Dist., 108 F. Supp. 72 (S.D. Cal. 1952). 
water rights of private water users or acquire them by exchange with such users. ${ }^{74}$ None of these methods is peculiar to the sovereign; any private person could acquire water rights similarly. However, there are some bases for governmental assertion of water rights which are not available to private claimants. The most obvious of these is the Government's "navigation servitude" under the commerce clause. This power over navigation is deemed to give the federal government a "dominant servitude" over all navigable waters in this country. ${ }^{75}$ Clearly, also, the Government may acquire water rights through the exercise of its traditional condemnation powers. ${ }^{76}$ Mioreover, it appears that the United States may now assert special water rights upon its "reserved lands."

The problem posed under the McCarran Amendment in this regard is in determining if it waives sovereign immunity to the adjudication of any and all governmental water rights, whatever their source, or whether the source of the particular governmental water right may be determinative of whether or not consent has been given to adjudicate it. The statute in its first sentence consents to adjudication or adininistration actions "where it appears that the United States is the owner of or is in the process of acquiring water rights by appropriation under state law, by purchase, by exchange, or otherwise ..."78 By its terms, then, the statute waives sovereign immunity to the adjudication of governmental water rights acquired by appropriation, purchase or exchange. The "or otherwise" provision would at least seem to clear the way for adjudication of riparian rights acquired by the Government under a State's riparian system.

When attention is shifted to those sources of water rights that are not available to the private user, however, the applicability of the statute becomes extremely doubtful. Consent to the adjudication must be found in the provisions of the first sentence of the statute, set out above, if it is to be found at all. Clearly none of the special governmental water rights is based upon an appropriation under state law or upon an "exchange." Nor are the rights arising from the navigation servitude or from use on reserved lands based upon a "purchase." However, it appears that the water right acquired by eminent-domain proceeding probably would be obtained by "purchase" within the meaning of the statute. Although the condemnation power is not exercisable by the ordinary private party, its effect is merely to force a "sale" and "purchase," with compensation moving from the Government to the condemnee in return for the latter's prater right.

Aside from the condemnation situation, consent to the adjudication of rights based upon special governmental powers inust be found in the "or otherwise" provision, if anywhere. This raises the question of whether the ejusdem generis doctrine should apply here, and if so, what its effect should be. This is a doctrine of construction arising when specific words are followed by a general term such as "or otherwise," and serves to limit the objects encompassed by the general term to the same class as those specifically enumerated. Obviously, the doctrine is inapplicable if the specific enumerations do not all fit into one definable class. Nor can it be employed if the specific terms exhaust the class or if the statute shows

74 Cf. Rank v. Krug, 142 E. Supp, 1, 117-21 (S.D. Cal. 1956).

75 United States v. Twin City Power Co., 350 U.S. 222 (1956); United States v. CbandlerDunbar Water Power Co., 229 U.S. 53 (1913); see Clyde, Current Developments in Water Law, 53 Nw. U.L. REv. 725, 730-34 (1959).

78 See, e.g., Town of Durbam v. United States, 167 F. Supp. 436 (D.N.H. 1958).

77 See FPC v. Oregon, 349 U.S. 435 (1955). "Reserved linds" are those withdrawn from public use or settlement, and are to be distinguished from "public lands."

7866 Stat. 560 (1952), 43 U.S.C. $\$ 666$ (1958). 
an intent that the general term be not limited to the class. ${ }^{79}$ It is purely a tool for determining legislative intent and is not an inflexible rule always to be followed. However, it is a doctrine well established in the law and has a legitimate use when properly applied. ${ }^{80}$

The specific terms in the first sentence of the McCarran Amendment ("by appropriation under State law, by purchase, by exchange") would seem to form a class. Each of them describes a method of acquisition available to the public at large as well as to the Government. ${ }^{81}$ They give no inkling of intent to include such governmental sources of water rights as the navigation servitude or the power over reserved lands. Nor do these specific terms exhaust the class, since the acquisition of water rights through ownership of riparian lands is not enumerated and would seem to be at least one further method of acquiring water rights available to the public. In addition, no intent is apparent in the statute to reach further than the aforementioned class by use of the words "or otherwise." Although the second sentence of the statute waives "any right to plead ... that the United States is not amenable [to state laws] by reason of its sovereignty ..., ${ }^{\prime 82}$ such a waiver does not indicate an intent that the first sentence serve as a consent to the adjudication of water rights acquired through special sovereign powers. That no such intent may be drawn from the second sentence is apparent from the fact that it is expressly limited by the first, applying to actions in which the United States has been made a party under the conditions imposed by the first sentence. 83

It seems clear from the above discussion that application of the doctrine of ejusdem generis is not only proper here but also is necessary in order to glean the legislative intent from the statute itself. Use of the doctrine leads to the conclusion that the "or otherwise" provision does not encompass the adjudication of water rights having a source in the powers over navigation and over reserved lands. These powers are peculiar only to the Government in this country and are not within the class enumerated by the specific terms in the first sentence of the statute. It should be noted, however, that water rights acquired by the Government under the Reclamation Act of 1902 would come within the enumerated class and would therefore be subject to the waiver of immunity, since section 8 of the act ${ }^{84}$ requires governmental compliance with state procedures in the acquisition of water rights; water rights thus acquired would have their source in state procedures available to the public and not in powers exercisable by the Government without regard to state law.

An examination of the legislative history of the McCarran Amendment uncovers no conclusive indications either way on the question of waiver of immunity

79 See 2 Sutherland, Statutory Construction $\$ 4910$ (3d ed. 1943).

80 But see ibid.

81 It should be noted that although the sovereign power of eminent domain may be said to be exercised "by purchase," that special sovereign power merely enables the Government to make the purchase when necessary. The Government must then go ahead and "purchase" the rights in a manner which, though not always marked by unfettered bargaining on both sides for the best deal, is comparable to the purchase of water rights by a private party. Moreover, it takes a construction of the McCarran Amendment to determine that acquisition by condemnation is included within the meaning of "purchase." Without question, the word "purchase" in the act contemplates purchase by the Government without the aid of condemnation, i.e., purchase in the same manner as a private party.

8266 Stat. 560 (1952), 43 U.S.C. $\$ 666$ (1958).

83 See text at note 87 infra.

8432 Stat. 390 , 43 U.S.C. \& 383 (1958). 
to suits for the adjudication of purely sovereign water rights. The committee report on the bill contains only one helpful passage. It reads:

Congress has not removed the bar of immunity even in its own courts in suits wherein water rights acquired under Stale law are drawn in question. The bill... was introduced for the very purpose of correcting this situation and the crils growing out of such immunity. $\mathbf{8 5}$

Since water rights held by virtue of the navigation servitucle or by virtue of use in conjunction with reserved lands are not "acquired under State law," the above excerpt may indicate that there was no intent to reach such rights in the statute.

The only possible contrary indication in the legislative history of the statute stems from a letter written by Mastin G. White, then Acting Assistant Secretary of the Interior, to Senator McCarran in opposition to the bill. In his letter, Mr. White set forth the general proposed terms of a waiver of immunity statute in this field which he felt would be acceptable to the Interior Department. These terms would have made it clear that no consent would be given for the adjudication of rights other than those acquired under state law. It might be argued that since Mr. White's suggested changes were not adopted (the bill instead having been later passed as it stood at the time of Mr. White's letter), Congress must have rejected the idea of limiting the waiver to rights acquired under state procedures and must have contemplated a broader waiver in the first sentence of the statute. Such an argument, however, would be highly speculative and might be met by the equally plausible contention that the committee (and Congress) thought the bill to have adequately expressed the narrow waiver suggested by Mr. White. There is no indication in the report on the reaction to Mr. White's letter other than that it was considered and its general approach of opposition to the bill rejected.

The legislative history of the statute on this point, then, is inconclusive at best. Congressional intent can be determined from the face of the act only with the help of the doctrine of ejusdem generis. Using that doctrine, it appears that consent is given to suits for the adjudication or administration of governmental water rights either obtained by proceeding under the state water laws or by a purchase or exchange at least similar in nature to those that could be made by a private party. There is no waiver of immunity with respect to suits concerning rights lodged in the Government by virtue of its navigation servitude or its power over reserved lands. ${ }^{86}$

\section{Existence of Special Rights in the United States Once It Has Been Joined Under the Statute}

The recent case of $N e v a d a$ v. United States ${ }^{87}$ presents the question of whether the Government, once it is joined by virtue of the McCarran Amendment, is pre-

${ }^{85}$ S. REP. No. 755, 82d Cong., 1st Sess. 5 (1951). (Emphasis added.)

86 None of the reported cases construing the McCarran Amendment have considered the importance of the source of the Government's tvater rights. In Rank v. Krug, 142 U.S. 1 (S.D. Cal. 1956), some of the Government's rights were purchased from private water users and some were in the process of being acquired through the state procedure, in accordance with $\$ 8$ of the Reclamation Act of 1902. Town of Durham v. United States, 167 F. Supp. 436 (D.N.H. 1958), involved a controversy over the taking of water rights by the Government under the power of eminent domam. In Nevada v. United States, 165 F. Supp. 600 (D. Nev. 1958), the Government based its claim on its power over reserved lands. The other reported cases construing the statute do not indicate the source of the governmental rights heing considered.

87 165 F. Supp. 600 (D. Nev. 1958). This case is currently pending on appeal before the Ninth Circuit. 
vented by the statute from raising defenses based upon the supremacy clause or upon other sovereign rights. In that case, the Government had drilled certain wells within the boundaries of the Hawthorne Naval Ammunition Depot, to tap underground water resources for use on the depot. In accordance with Nevada law, the commanding officer of the depot filed an application with the state engineer for a permit to appropriate the underground water. However, the application was never completed by filing the required proofs of application to beneficial use of the water, the Government taking the position that it was not subject to the state permit requirements because the water was to be used upon its "reserved land" occupied by the depot. The State thereupon brought this declaratory judgment action to determine the Government's status under the state appropriation laws. It was held that the United States was not subject to the state regulatory system and that it therefore needed no permit in order to appropriate the underground water for use on the depot.

The action was brought under the McCarran Amendment. The court did not discuss the question of whether the statute had waived sovereign immunity to this type of suit, but rather focused its attention on the federal rights asserted by the Government in defense to the action. The McCarran Amendment was briefly discussed with respect to whether it served as a waiver by the Government of its sovereign defenses once it had become a party to the suit under the statute. The second sentence of the statute provides:

The United States when a party to any such suit, shall (1) be deemed to have waived any right to plead that the State laws are inapplicable or that the United States is not amenable thereto by reason of its sovereignty, and (2) shall be subject to the judgments, orders, and decrees of the court having jurisdiction, and may obtain review thereof, in the same manner and to the same extent as a private individual under like circumstances....88

To the argument that this provision waived the Governnent's right to assert its immunity from the state water law, the court in Nevada $v$. United States had this to say:

This does not mean, however, that the United States cannot invole Federal statutes and decisions in support of its claim that it need not obtain a permit from the State to use underground waters in a naval installation. This Court does not believe that the defendant stultified itself by giving its case away in advance: All laws, both State and Federal, are to be considered in this case, insofar as they are relevant. 89

Thus, rather than discussing the basic problem of whether the Government under the statute had consented to this type of suit at all, the court decided in favor of the Government by virtue of a narrow construction of the second sentence of the statute. A strong argument may be made that the McCarran Amendment does not waive immunity to suits such as this, since here the United States was a sole defendant and was not "joined" as a necessary party defendant within the meaning the statute, and since this was not a suit "for the adjudication of rights to the use of water" as contemplated by the statute. Moreover, the Government's clain was based on its power over reserved lands; although the court considered the reserved lands point, it did not do so with respect to the first sentence of the statute and thus did not determine the importance of the power over reserved lands for purposes of the basic waiver of immunity.

8866 Stat. 560 (1952), 43 U.S.C. 666 (1958).

89165 F. Supp. 600, 604 (D. Nev. 1958) (emphasis by the court). 
The second sentence of the statute raises difficult questions as to its scope. Primary among these is the question of whether the Government has gone so far as even to waive those defenses based upon the Constitution, or whether it has waived only those sovereign defenses that may be classified as "non-constitutional." If it has waived even those founded on the Constitution, it will be precluded by the second sentence not only from asserting rights based upon its navigation servitude (which stems from the commerce clause), but also from raising defenses under such constitutional provisions as the supremacy clause. It is unlikely that Congress intended to go so far. Rather, the second sentence probably should be read as waiving any right to plead that state laws are inapplicable insofar as those laws would not conflict with the federal constitution if applied. Moreover, it may be argued that the United States is not pleading immunity from state laws by reason of its sovereignty when it pleads immunity from them by reason of its constitutional privileges. That such privileges may have been granted to it in the constitution because of its sovereign position should make no difference. Congress, if it had wished to waive even the Government's constitutional rights, would have done so in clear and unmistakable language.

The court in Nevada v. United States permitted the Government to raise three defenses, all three of which it accepted as grounds for its decision. Since the action was brought under the McCarran Amendment, it is of some importance to test these three defenses by the waiver set forth in the second sentence of the statute. Two were based directly upon the Constitution, one being the supremacy-clause defense founded upon $M c$ culloch v. Maryland ${ }^{90}$ and the other concerning the possible interference with national defense caused by the state regulation. As noted above, the statute probably does not preclude such defenses. However, the third defense, based on The Pelton Dam Case, ${ }^{91}$ was to the effect that governmental compliance with state procedures was unnecessary because the water was being tapped for use upon reserved land. The rights enjoyed by the Government in connection with reserved land are proprietary in nature, and do not spring directly from any constitutional provision. ${ }^{92}$ Since these are "sovereign" rights, it would seem that the United States by pleading a defense based on its power over reserved land is pleading that it is not amenable to state law by reason of its sovereignty, in disregard of the waiver found in the McCarran Amendment's second sentence. ${ }^{93}$

8017 U.S. (4 Wheat.) 316 (1819).

91 FPC v. Oregon, 349 U.S. 435 (1955).

92 Ibid.

93 This of course assumes that the United States has properly been joined by virtue of the first sentence of the statute, which probably was not the case in Nevada $v$. United States. Often, the very fact that the Government is claiming the water for use on reserved land should prevent joinder under the first sentence. In such a case, the question of whether the second sentence waives defenses based on the power over reserved land should not be reached. However, if the Government's water right in question has been acquired by compliance with state procedures, there should be no question that the Government may be joined under the first sentence even though the water is used on reserved land. Then the second sentence would fulfill the purpose of waiving any defenses the Government might otherwise have had by virtue of its use on reserved land. It should be noted also that an analogous situation exists with respect to the Government's navigation servitude, i.e., the fact that the Government's claims are on a navigable stream may prevent joinder under the first sentence, but if it complied with state law to get its rights it may be joined despite the navigable character of the stream. However, in this case the second sentence of the statute would not itself preclude the Government from relying on its constitutional power over navigation as a defense. Such a preclusion has instead been found independently of the statute where the Government has complied with state law in acquiring water rights on navigable streams. See United States ४. Gerlach Live Stock Co., 339 U.S. 725 (1948). 
There is little doubt that the Government may waive whatever exclusive power it enjoys over reserved land under The Pelton Dam Case, and that it has done so at least where the reserved-land factor has not prevented joinder of the sovereign under the statute's first sentence. ${ }^{04}$

Rank v. Krug is the only other case that has considered the effect of the second sentence of the statute with respect to special rights of the Government as a defendant. It was held in Rank v. Krug that a default judgment could be entered against the United States, one of the grounds being that it had consented in the statute to be subject to the judgments of the court having jurisdiction "in the same manner and to the same extent as a private individual under like circumstances." 95 This more liberal attitude in Rank v. Krug toward the Government's waiver of non-constitutional special privileges once the statute is found to apply is in keeping with the broad wording of the statute's second sentence.

Although the first sentence of the statute, defining those suits in which sovereign immunity is waived, operates as a somewhat narrow waiver applying only to a certain type of suit, the second sentence is a broad and inclusive waiver of sovereign privileges, though probably not of constitutional privileges claimed by the sovereign. The second sentence comes into play once the conditions of the first sentence have been met.

\section{E. Application of the Statute When the United States Has Instituted the Suit}

There is one interesting discrepancy in terminology between the first and second sentences of the McCarran Amendment. In the first sentence consent is given to join the United States as a "defendant" in suits for the adjudication or administration of rights to the use of water, while the waiver in the second sentence applies whenever the United States is a "party to any such suit." ond sentence is not by its terms limited to the situation in which the Government is a defendant in the action. However, it is limited in its application to a suit of the nature in which the Government could be properly joined as a defendant under the first sentence, since it refers back to the type of suit contemplated in the first sentence by saying "any such suit."

The most logical interpretation of this difference in terminology within the statute is that the second sentence is meant to insure the consent of the GovernInent to the full state procedure in actions to determine priority of rights to the use of water, even if the Government itself has initiated the suit. Thus the Government in such a case could not assert its immunity from a decree in the nature of that used in California to accomplish a "physical solution," on the ground that such a decree would be more than an adverse decision and therefore would require some affirmative waiver other than the mere bringing of the suit by the United States. The statute has in fact been cited as supplying a waiver in this context, in California v. Unitcd Statcs. ${ }^{97}$ That case, one of the appeals in the Fallbrook litigation, involved a quiet-title action brought by the United States against some

94 Cf. United States v. Fallbrook Pub. Util. Dist., 165 F. Supp. 806 (S.D. Cal. 1958), setting forth the stipulation of the United States in that protracted litigation, to the effect that the Gorernment's claim to water for its Camp Pendleton "reserved" land amounted only to that which it could acquire in accordance with state law and procedure. See note 93 supra.

95 Rank v. Krug, 142 F. Supp. 1, 89 (S.D. Cal. 1956).

0666 Stat. 560 (1952), 43 U.S.C. $\$ 666$ (1958). (Emphasis added.)

0i 235 F.2d 647 (9th Cir. 1956). 
three thousand water users. Such a case clearly is a suit "for the adjudication of rights to the use of water" within the meaning of the McCarran Amendment, although here the United States was the plaintiff rather than the defendant and thus no consent to the suit itself was necessary. The court cited the statute for the proposition that the district court by its final judgment could grant complete relief as to all claimants and the United States, including a "physical solution." 08 In effect, the Government as a "party" to the proper type of suit had merely subjected itself to the "judgments. orders, and decrees of the court having jurisdiction," as provided in the statute.

It would seem also that the statute's second sentence would supply a governmental waiver of such sovereign privileges as that based on The Pelton Dam Case even if the Government itself has brought the action, provided that it is the proper type of suit as tested by the conditions found in the first sentence. Although California $\%$. United States involved governmental claims of water rights on reserved land, thus presenting a situation similar to that in Nevada v. United States $5^{00}$ where a claim of special right might be made on the strength of The Pelton Dam Case, the court had no occasion to discuss the significance of the McCarran Amendment on this point since the Government had entered into a stipulation whereby it claimed no greater rights than could be acquired under the standard California procedures. Consequently there is no case considering the effect of the second sentence of the statute on rights peculiar to the sovereign, when the Government has itself brought the suit. It would seem, however, that although the inited States probably could not be joined as a defendant under the first sentence if its rights are based on sovereign privileges or powers and have not been acquired under state law, it could subject itself to the waiver in the second sentence at least with respect to its sovereign power over reserved land when it initiates the action. It would then be "a party to any such suit," i.e., to a suit for the adjudication or administration of rights to the use of water, and would have waived any contentention of immunity stemming from the source of its water rights by bringing the action. It may be questioned, however, whether the Government ever waives its rights based on the navigation servitude. Probably even the initiation by it of a proper MICCarran Amendment suit would not serve to waive such rights. ${ }^{100}$

It would not seem that the second sentence of the statute could be interpreted to go further and subject the Government to counterclaims, cross-complaints, or claims in intervention in suits brought by it to adjudicate "rights to the use of water," other than the normal assertions of water rights made by all claimants in such an action. ${ }^{101}$ The clear purpose of the statute is only to provide a system whereby such water rights may be determined among all users including the United States. It does not anywhere comprehend the assertion of any other rights against the Government. Viewing the statute as a whole, it is apparent that the second sentence must be read only as waiving any right to plead that state water laws are inapplicable, and not as waiving sovereign immunity to independent counterclaims based upon liberal state laws relating to trial procedure. Moreover, the

98 Id. at 652-53.

99165 F. Supp. 600 (D. Nev. 1958). For discussion of this case, see text at note 87 supro. 100 See note 93 supra.

101 In most cases, the applicable rules of procedure will prevent the assertion of claims other than those for priority of right to the use of water in such artions, by requiring a connection between the asserted claim and the plaintiff's original cause of action. See, e.g., Car. CODE Crv. Proc. $\$ \S 437-42$. 
statute's second sentence, unlike its first sentence, does not waive immunity for the adjudication of any rights and thus cannot be interpreted as providing the consent necessary to the adjudication of independent rights against the Government. It is apparent from these factors that the use of the word "party" in the second sentence rather than "defendant" serves only to subject the Government to the full determination of all interrelated rights to the use of water, even if the Government has itself initiated the suit as it did in the Fallbrook litigation.

\section{F. The Applicability of the Statute in Administrative Proceedings}

A serious problem is raised as to whether the statute waives sovereign immunity for administrative proceedings as well as for court actions. The "general determination" process in a few Western States is carried on before an administrative agency rather than by judicial action. ${ }^{102}$ Thus if the statute does not apply to adninistrative hearings, Congress has lifted the bar of sovereign immunity for "general determination" proceedings in some States but not in others.

The statute gives consent to join the Government as a "defendant" in "any suit" for the "adjudication" or "administration" of rights to the use of water if the United States is a "necessary party to such suit." It goes on to make the Government "subject to the judgments, orders, and decrees of the court having jurisdiction." It seems clear that use of the word "administration" among all the words in the statute connoting judicial proceedings does not indicate an intention to restrict the application of the statute to administrative proceedings. ${ }^{103}$ There should be no question that it may be applied in a proper case in the federal courts, if the necessary grounds for federal jurisdiction are present. ${ }^{104}$ Nor do the terms of the statute refute a construction finding it applicable in proper state-court proceedings. Rather, such broad terminology as "any suit for the adjudication of rights to the use of water" and "the court having jurisdiction" would seem to leave little doubt that the statute may be utilized in the state courts.

However, it is unlikely that the statute may be taken to comprehend state administrative proceedings. This is so even though the proceedings in those States which use the administrative method to determine rights to the use of water are substantially similar to the judicial proceedings which serve the same purpose in other States and to which the statute clearly applies. Although administrative agencies might be said to "adjudicate" rights to the use of water, within the meaning of the statute, ${ }^{105}$ it encompasses only "suits" for the adjudication or administration of water rights. Proceedings before administrative bodies are not "suits" within the generally accepted meaning of that term. ${ }^{100}$ The second sentence of the statute, defining the extent of the Government's waiver once proper joinder has

102 This is the "Wyoming system," exemplifed by Wyo. Cosur. Stat. Ans. $\$ \S 41-165$ to -192 (Supp. 1957).

103 This is the conclusion reached in Rank v. Krug, 142 F. Supp.. 1, 73-75 (S.D. Cal. 1956).

Cf. In re Green River Drainage Area, 147 F. Supp. 127, 135 (D. Utah 1956).

104 Cf. In re Green River Drainage Area, supro note 103. See text at note 124 infra.

105 The Wyoming statute describes its administrative procedure as an "Adjudication." Wyo. Cosrp. Stat. Ans. \$§ 41-165 to-192 (Supp. 1957). See Laramie Irr. \& Power Co. v. Grant, 44 Wyo. 392, 13 P.2d 235, 242 (1932). Cf. the California "statutory adjudication" system, which amounts to a bybrid combining administrative and judicial action. CAL. WATER CODE $\S \S 2500-2900$.

${ }^{108}$ Rank v. Krug, 142 F. Supp. 1, 73 (S.D. Cal. 1956); In re Silvies River, 199 Fed. 495, 501 (D. Ore. 1912); cf. Lambert v. Texas Employers' Ins. Ass'n, 121 S.W.2d 406, 408 (Tex. Civ. App. 1938). 
been accomplished under the first sentence, provides only for the subjection of the United States in "such suit ... to the judgments, orders, and decrees of the court having jurisdiction." 107 In view of such terminology in the statute, it seems almost impossible to interpret it as permitting its application to administrative determinations of the relative rights to the use of water on a stream or other water source. The result, for all practical purposes, is a waiver of sovereign immunity in some States but not in all, with respect to the determination of such interrelated water rights. ${ }^{108}$ No reasonable ground appears for the distinction. ${ }^{100}$ This probably is the result of a drafing error which might easily be corrected by the addition of a few words to the statute extending its scope to include administrative determinations of relative rights to the use of water in States where an administrative procedure has supplanted judicial determination. ${ }^{110}$

It is important at this point to inquire into the applicability of the statute in Cahfornia, where proceedings to determine the relative priorities of water users involve a combination of the judicial and administrative functions. ${ }^{111}$ Priorities to the use of water in Cahfornia may be determined in either of two ways: (1) under the "court reference" procedure by which suit is filed in state or federal court, either of which may order a reference to the state water rights board for initial determination of the priorities; 112 or (2) under the "statutory adjudication" procedure by which a petition is filed directly with the board and the resulting order of determination by the board is forwarded to the superior court for a further hearing and decree. ${ }^{113}$ Both of these procedures result in the relative priorities being fixed by court decree rather than by the administrative determination.114

There is little doubt that the MICCarran Amendment would apply to a proceeding brought to determine the relative priorities of rights in which the court reference method is utilized. It is in every sense a "suit" with a judicial decree deter-

10766 Stat. 360 (1952), 43 U.S.C. $\$ 666$ (1958). (Emphasis added.)

108 In Wyoming the administrative procedure is the exclusive method by which the relative priorities on a stream may be adjudicated. Campbell v. Wyoming Dev. Co., 55 Wyo. 347, 100 P.2d 124, rehearing deried, 102 P.2d 745 (1940).

109 It is to be noted that even if the court in Rank v. Krutg were correct in extending the statute to permit suits other than those adjudicating rights against all claimants, it would still apply to judicial actions of the "general determination" type but not to similar administrative proceedings. Clearly waiver of sovereign immunity in the "general determination" situation is at least one of the purposes of the statute. Thus the discrimination in the statute between judicial and administrative "general determmations" seems unavoidable under any interpretation.

110 To avoid possible undesired applications of the statute in proceedings other than those of a "general determination" nature, any amendment should include also an express statement of the over-all scope of the statute, either clearly broadening it to encompass such cases as Rank v. Krug or removing all question as to its present rather restricted scope.

111 For an example of the combination judicial-administrative procedure in a State other than California, see ARIz. REv. STAт. Axx. $\$ \S 45-231$ to -245 (1956). Since the Arizona system is practically identical to that in effect in California, what is said with regard to the applicability of the MicCarran Amendment in California applies equally to Arizona.

112 Cas. WATER CODE $\$ \S 2000,2075$. This "court reference" procedure has heen utilized in two reported cases involving the "general determination" type of suit. City of Pasadena y. City of Albambra, 33 Cal. 2d 908, 207 P.2d 17 (1949), cert. denied, 339 U.S. 937 (1950) ; Fleming v. Bennett, 18 Cal.2d 518, 116 P.2d 442 (1941).

113 The "statutory adjudication" procedure is found in CAL. WATER CODE \$\$ 2500-2900.

114 Fleming v. Bennett, $18 \mathrm{Cal} .2 \mathrm{~d}$ 518, 524, 116 P.2d 442, 445 (1941) (court reference); Wood v. Pendola, 1 Cal. 2d 435, 35 P.2d 526 (1934) (statutory adjudication). For a discussion of both the court reference and the statutory adjudication systems in California, see Ferrier, Administration of Water Rights in Californic, 44 CaLIF. L. REv. 833, 843-48 (1956). 
mining the rights, the board being used only as a referee. ${ }^{115}$ There is nothing in the statute or in its legislative history to indicate that the Government's consent to the suit terminates with the reference of the issues to a referee.

A more difficult question is presented, however, with respect to the statutory adjudication procedure. Although the proceeding is initiated by an administrative determination of the various rights, it is clear that this determination is not final without a subsequent court decree. The administrative order and transcript must be filed with the clerk of the superior court, ${ }^{110}$ and that court then must hold a hearing ${ }^{117}$ in which exceptions to the administrative determination may be presented ${ }^{118}$ and in which additional evidence may be taken. ${ }^{119}$ The order of determination, the statements or claims of claimants, and the exceptions to the order of determination constitute pleadings in the superior court hearing. ${ }^{120}$ After the hearing, the court enters a decree "determining the right of all persons involved in the proceeding." 121 Such provisions are not customarily associated with appellate review; on the contrary, they are appropriate only for trial court proceedings. ${ }^{122}$ Provision is also made specifically in the statutory adjudication portion of the California Water Code to join the State as a "necessary party to the action."123 Thus a strong argument may be made that the filing of the board's order of determination and transcript with the superior court would constitute the initiation of a "suit for the adjudication of rights to the use of water" within the meaning of the McCarran Amendment and that the United States, like the State of California, could be joined as a necessary party to the action.

\section{G. Federal Jurisdiction Problems Under the McCarran Amendment}

A number of technical problems in the field of federal-question jurisdiction presented by the McCarran Amendment deserve brief mention.

First of these is whether the consent statute itself will serve as a basis for federal-question jurisdiction under 28 U.S.C. section 1331. The leading case, In re Green River Drainage Area, ${ }^{124}$ answers this question in the negative. While recognizing that such jurisdiction might be constitutionally possible under the holdings of Osborn v. Bank of United States ${ }^{12 \bar{v}}$ and The Pacific Railroad Removal Cases, ${ }^{126}$ the case rejects such jurisdiction as not included in the statutory grant,

115 CAL. WATER CODE $\S 2000$.

116 CAL. WATER CODE $\$ 2750$.

117 CAL. WATER CODE $\$ 2751$.

118 CAL. WATER CODE $\$ 2763$.

119 CAL. WATER CODE $\$ 2767$.

120 CAL. WATER CODE $\$ 2760$.

121 CAL. WATER CODE $\$ 2768$.

122 For holdings that the superior court in these statutory adjudications does not act in an appellate capacity but rather as a trial court, see Wood v. Pendola, 1 Cal. 2d 435, 35 P.2d 526 (1934); Bray v. Superior Court, 92 Cal. App. 428, 268 Pac. 374 (1928). To the same effect under the similar Arizona procedure, see Stuart v. Norviel, 26 Ariz. 493, 226 Pac. 908 (1924). 123 CAI. WATER CODE $\$ 2765$.

124147 F. Supp. 127 (D. Utah 1956). Nevada v. United States, 165 F. Supp. 600 (D. Nev. 1958), appears to be impliedly contrary to Green River, since the defense of the United States based upon "sovereign rights" would presumably appear only defensively. Since the court did not consider the jurisdictional problem in its opinion in that case, however, the assumed basis of jurisdiction is a matter of conjecture.

12522 U.S. (9 Wheat.) 738 (1824).

120115 U.S. 1 (1885). 
based upon cases such as Gully v. First Nat'l Bank, ${ }^{127}$ in which a state tax suit against a national bank was held not removable even though the levy of the tax was permissible only by reason of a federal statute. The analogy seems very closely in point, both cases involving federal statutes merely permitting suit on a cause of action arising under state law. 128

Also rejected was the theory that the presence of the United States as a defendant conferred federal-question jurisdiction. ${ }^{120}$ Congress is, of course, free to provide original federal jurisdiction in any case in which the United States is a party, and to condition its waiver of sovereign immunity upon the bringing of suit against the United States in a particular court. The holding here simply is that Congress has not done so in the grant of federal-question jurisdiction in 28 U.S.C. section. 1331 or otherwise. A special jurisdictional grant exists for actions commenced by the United States, ${ }^{130}$ but not actions brought against it.

In the absence of federal-question jurisdiction based upon one of the above grounds, it will be necessary for actions under the McCarran Amendment to be brought in state courts unless some independent ground of original federal jurisdiction exists. Three such possible grounds, 28 U.S.C. section 2410 (actions to foreclose a lien, or to quiet title to, property on which the United States claims a mortgage or lien), 28 U.S.C. section 2201 (declaratory judgments), and 28 U.S.C. section 1347 (action for partition in lands in which United States is a joint tenant or tenant in common), were considered in the Green River case and rejected. The applicability of these statutes will depend on the nature of the proceeding, however. A more probable ground of original federal jurisdiction in future litigation is federal-question jurisdiction based upon disputed construction of some federal statute affecting the claims of the United States, other than the consent statute.

A second problem has been raised as to joinder. In view of the liberal provisions of the Federal Rules of Civil Procedure no difficulty in this area might be anticipated. The novel theory has recently been put forth that the joinder of the United States as a defendant in a suit also alleging action in excess of authority by defendant federal officials constitutes an admission that the officials acted within their authority. The court rejected the contention, using the analogy of a suit against a corporation and its agents. ${ }^{131}$ The result seems proper, since inconsistent pleadings are permissible in federal court. ${ }^{132}$ Moreover, relief may be required against both the officials and the United States, as where the former have concluded an invalid contract on behalf of the latter and declaratory relief annulling it is sought.

A third question is that of venue in federal court for suits under the McCarran Amendment. No case has been located specifically dealing with the issue, but it

127299 U.S. 109 (1936). The court also cites Puerto Rico v. Russell \& Co., 288 U.S. 476 (1933), in which a territorial tax suit was held not to present federal-question jurisdiction for purposes of removal even though the right of the territory to levy taxes and bring suit depended upon an act of Congress; and Gableman v. Peoria, D. \& E. Ry., 179 U.S. 335 (1900), in which the federal nature of a receiver in bankruptcy was held not to create federal jurisdiction.

128 See the treatment in Hart \& Wechsler, The Federar Courts and tye Federar SySTEAr 764 (1953).

129 The court relied upon Wells v. Long, 162 F.2d 842 (9th Cir. 194\%), which so held. Accord, Santa Margarita Mut. Water Co. v. State Water Rights Bd., 165 F. Supp. 870 (S.D. Cal. 1958).

13028 U.S.C. $\$ 1345$ (1958).

131 Rank v. Krug, 142 F. Supp. 1, 79-80 (S.D. Cal. 1956).

132 FED. R. CIV. P. $8(e)$. 
would seem that since consent is given to "join" the United States in "any suit" venue ought to exist to join the United States in any federal court in which the suit is otherwise properly brought. A brief dictum in an unrelated case supports this view. ${ }^{133}$ The problem has been avoided heretofore by brimging suit in a state court.

A final issue concerns removal jurisdiction where a McCarran Amendment action has been brought in a state court. The statute is silent on the point. The legislative history of the statute was examined in the Green River case, however, showing (1) that a clause providing for removal was deleted from the legislation prior to passage and (2) that a provision prohibiting removal proposed by the National Reclamation Association was not adopted. From this it is concluded that the legislative intent was to allow removal only where it is independently provided for under existing statutes. ${ }^{134}$ Since the general removal statute ${ }^{135}$ ties removal jurisdiction to the existence of original jurisdiction, failure of the latter will normally defeat the former. ${ }^{136}$ Special removal statutes must, of course, be consulted. Where a federal officer is joined as a defendant, he will have a right of removal, ${ }^{137}$ which in practice will no doubt be exercised for the benefit of the United States, since the United States customarily defends actions against its officers.

A collateral problem may arise after removal where the United States seeks dismissal on the ground the consent statute is not applicable, while the plaintiff seeks remand to the state court for lack of removal jurisdiction. Where removal jurisdiction is in fact lacking the sequence in which rulings are made upon the motions may determine whether the applicability of the statute, as well as any other grounds urged for dismissal, is ruled upon by the federal or the state court. Since both issues are jurisdictional the problem is not simple, but it would appear that the proper procedure is to rule first on the motion to remand, leaving the question of dismissal to the state court. ${ }^{138}$

133 "Liberalized venue statutes ... should be applied in the liglt of the long time effort of Government administrators and agencies to hide behind Government immunity; and when sued by a citizen aggrieved, to insist that the suit could only be maintained in the District of Columbia.... [This] provides background for statutes like 12 U.S.C.A. $\$ 1702$ and 43 U.S.C.A. \$ 666." Mooreland Court, Inc. v. Mason, 137 F. Supp. 193 (D. Ore. 1955).

134 In re Green River Drainage Area, 147 F. Supp. 127, 136-38 (D. Utah 1956).

13528 U.S.C. $\$ 1441$ (1958).

136 This was the case in Green River. See also Santa Margarita Mut. Water Co. v. State Water Rights Bd., 165 F. Supp. 870 (S.D. Cal. 1958), in which removal of a state proceeding for judicial review of administrative action granting the application of a private party to appropriate water and denying that of the United States failed for the same reason.

13728 U.S.C. $\$ 1442$ (1958).

138 See In re Bear River Drainage Dist., 267 F.2d 849 (10th Cir. 1959). The contrary procedure was followed, however, in Town of Durhain v. United States, 167 F. Supp. 436 (D.N.H. 1958). The problem presented in the McCarran Amendinent cases should be distinguished from that presented in cases involving actions against government officers, discussed in text at note 34 supra, in which removal jurisdiction exists but jurisdiction of the real party defendant, the United States, does not. In the McCarran Amendment situation both types of jurisdiction are disputed. Remand bas also been held the proper procedure in the analogous situation where a labor relations case has been removed from state court and it appears that both federal and state courts are without jurisdiction because of the primary jurisdiction of the NLRB. Gwaltney Bros. v. Marion County Bldg. Trades Council, 175 F. Supp. 790 (S.D. Ind. 1959).

Since rulings upon motions to remand are normally not reviewable either by appeal or by extraordinary writ, the issue is apt not to be litigated beyond the district court level. See 28 U.S.C. \& 1447 (d) (1958). But see Santa Margarita Mut. Water Co. v. State Water Rights Bd., 165 F. Supp. 870 (S.D. Cal. 1958), in which the effective date of the order of remand was postponed in order to give opportunity for review by extraordinary writ. 


\section{CONCLUSION}

Problems with respect to joining the United States in water litigation are far from wholly solved by the McCarran Amendment. Its probable narrow scope, both as to the nature of suit meant to be covered and as to the particular types of governmental water rights made hitigable, leaves a large area in which no judicial remedy may exist for injury to water rights if the Government has a sufficient interest in the litigation to be classed as an indispensable party and has not waived its immunity through such federal statutes as the Tucker Act. Thus plaintiffs in water litigation will often be thrown back to such traditional methods of avoiding the necessity of joining the United States as the joinder of only the appropriate governmental official in hopes that the Government itself will not be indispensable. However, within the restricted scope of the McCarran Amendment, a full waiver of those sovereign privileges which do not stem directly from any constitutional provision seems to have been intended. Consequently, any action that fits the technical description of a "suit for the adjudication of rights to the use of water," in which the type of governmental water right does not prevent joinder under the first sentence of the statute, should be free from such sovereign defenses as that based on the Government's power over reserved land or based on any other sovereign power not stemming directly from constitutional privilege. Within this area at least, complete relief against the Government should now be available.

James W. Dilworth

Frederic L. Kirgis, Jr. 